Сабадош М.В., Дуткевич-Іванська Ю.В., Русин Л.П.

\title{
Вплив аквааеробіки на стан дихальної системи у дітей молодшого шкільного віку, хворих на хронічний бронхіт в стадії ремісії
}

\author{
ДВНЗ «Ужгородський національний університет», м. Ужгород, Україна
}

sabadosh.marjana777@gmail.com, yuliya101010@ukr.net, ljudarusyn@gmail.com

Сабадош М.В., Дуткевич-Иванская Ю.В., Русин Л.П.

Влияние аквааэробикой на состояние дыхательной системы у детей младшего школьного возраста, больных хроническим бронхитом в стадии ремиссии ГВУЗ «Ужгородский национальный университет», г. Ужгород, Украина
Sabadosh M.V., Dutkevych-Ivanska Y.V., Rusyn L.P. The effect of aqua aerobics on the respiratory system of primary school age children with bronchitis in remission State University "Uzhhorod National University", Uzhhorod, Ukraine

\section{Вступ}

Одним із пріоритетних напрямків охорони дитинства $€$ зниження частоти захворюваності та сприяння розвитку дитини. За результами останніх статистичних досліджень структури захворюваності дітей, перше місце займають хвороби дихальної системи [1], а також виявлено тенденцію до зростання показників захворюваності та поширеності хвороб органів дихання [22]. Неспецифічні запалення дихальних шляхів 3 частими повторними епізодами їх виникнення розповсюджені серед дітей і практично не превентуються, а самі епізоди захворювань погано лікуються, що і зумовлює актуальність проблеми [3]. Патологічні процеси, що пов'язані зі захворюваннями органів дихання, наростають з року в рік.

Патогенез хронічного бронхіту складний. На відміну від ХБ дорослих, де у виникненні і розвитку захворювання суттєву роль грають летучі полютанти та неіндиферентний пил, у дітей основне значення надається інфекційним факторам [4,5]. Розвиток хронічного запалення в бронхах, як правило, пов'язують 3 перенесеними в ранньому віці гострими респіраторними захворюваннями [6,7].

Ранній і точний діагноз лежить в основі забезпечення раціональним i оптимальним відновним лікуванням i зведення нанівець ризиків прогресування та трансформації захворювання у більш складні, тому діти з захворюваннями дихальної системи потребують пристальної уваги.

Фізична реабілітація дітей з хронічними бронхітами може суттєво поліпшити їх якість життя, знизити ризик прогресування і хронізації захворювання. Підвищувати ефективність відновного і оздоровчого впливів необхідно за рахунок комплексного, оптимального використання як традиційних, так і зовсім нових засобів і методів фізичної культури.

Мета - оцінити вплив аквааеробіки на функціональний стан системи дихання та толерантності до фізичних навантажень, у дітей молодшого шкільного віку, хворих на хронічний бронхіт в стадії ремісії.

\section{Матеріали та методи}

У ході аналізу історій хвороб нами були використані дані дітей $(\mathrm{n}=109)$, що були скеровані та поступали на санаторно-курортне лікування до санаторію «Малятко» (м. Ужгород), з діагнозом «хронічний бронхіт».

Застосування спірографічного методу дослідження дозволило отримати дані про об'ємні показники, що відображають функціональні можливості системи дихання.

\section{Результати дослідження та їх обговорення}

Заняття з аквааеробіки базувалися і враховували те, що у дитячому віці, як і впродовж усього життя людини, для повноцінного оздоровлення необхідне задоволення об'ємів фізіологічної норми рухової активності, як необхідної умови нормального розвитку та функціонування організму.

Аквааеробіка - це комплекс сучасних оздоровчих систем, що базуються на виконанні вправ вибіркової спрямованості аеробного характеру у водному середовищі.

Горизонтальне положення тіла у воді під час плавання, рівномірний тиск води на шкіру, iї масажна дія підсилюють обмін речовин, активізують життєві функції організму, збільшують частоту серцевих скорочень i покращують легеневу вентиляцію. Занурення людини у воду викликає переміщення крові з периферії, збільшує кровотік в органах грудної порожнини. Перебування у воді створює опір рухам грудної клітини, кінцівкам i збільшує опір потоку повітря. За рахунок підвищення внутрішньочеревного тиску знижується об'єм легенів, посилюється робота апарату зовнішнього дихання. Для виконання фізичних вправ у воді, тобто в умовах в'язкого 
середовища, дитині потрібно значно більше зусиль, ніж на суші.

При виконанні вправ звертається увага на те, що дихання через ніс вважається правильним і викликає відносно сильний спротив на вдиху, що необхідно для постійного збудження i напруження дихальних м'язів грудної клітки і діафрагми і підтримання постійного об'єму грудної клітки.

Аквааеробіка проводилася у басейні з температурою води не нижче $28^{\circ} \mathrm{C}$. Стандартна методика аквааеробіки включала більшість класичних вправ, зокрема «поплавок», «медуза», вправи на ковзання, різні види ходьби, елементи плавання стилем «кріль» та «брас», ігри.

Заняття 3 аквааеробіки складалося 3 вступної, основної та заключної частин. Вступна частина була спрямована на підготовку організму (суглоби, м'язи, систему кровообігу і нейром'язову систему) до фізичних навантажень основної частини, тому вона включала вправи, які викликають бажані реакції органів, та проводилася на суші. Всі вправи вступної частини заняття починалися 3 невеликої амплітуди руху з поступовим іiі збільшенням. Основу складали вправи для підготовки окремих суглобів, які будуть виконувати більшу частину роботи в основній частині. Оскільки в воді зменшується навантаження на нижні кінцівки роль ніг до певної міри знижена. Опір води потребує значного використання гребкових рухів верхніми кінцівками для пересування i збереження рівноваги. Тому перевага віддавалася розминці верхніх кінцівок. Розминка планувалася після складання плану вправ основної частини заняття.

Перші заняття 3 аквааеробіки щадного рухового режиму були спрямовані на адаптацію дітей до водного середовища та до виконання фізичних вправ у ньому, ознайомлення з фізичними властивостями води.

Заняття 3 аквааеробіки на щадно-тренуючому проводилося 3 дещо збільшеною тривалістю порівняно 3 щадним руховим режимом, а також змінювалися вправи вступної та основної частин, а саме застосовувалися більш складні координаційно і інтенсивніші вправи, вправи для формування правильної постави. Тривалість процедури доводилася до 45 хв, через день.

Спірографічне дослідження обмежувалося одним тестом для діагностики типу і ступеня вентиляційних порушень: проведенням тесту життєвої ємності легень (ЖЕЛ).

Дані, що представлені у таблиці, відображають стан системи дихання дітей 3 ХБ до та після занять 3 аквааеробіки. Достовірні відмінності між показниками до та після занять встановлені за ЖЕЛ $(\mathrm{p}<0,01), \mathrm{C}_{\text {вд }}(\mathrm{p}<0,01)$ i $\mathrm{PO}_{\text {вид }}(\mathrm{p}<0,01)$.

Заняття 3 аквааеробіки позитивно вплинули на функцію зовнішнього дихання, що підтверджується достовірним збільшенням життєвої ємності легень, і відповідно ії складових, у всіх показниках $(\mathrm{p}<0,001)$.

\section{Таблиця. Середньостатистичні показники тесту життєвої смності легень дітей з хронічним бронхітом}

\begin{tabular}{|c|c|c|c|c|c|}
\hline \multirow[b]{2}{*}{ Показники тесту життсвої ємності легень } & \multicolumn{2}{|c|}{ До } & \multicolumn{2}{|c|}{ Після } & \multirow[b]{2}{*}{$\mathbf{p}$} \\
\hline & $\bar{x}$ & $S$ & $\bar{x}$ & $S$ & \\
\hline ЖЕЛ, \% від належного & 77,94 & 1,80 & 90,35 & 1,67 & $<0,01$ \\
\hline $\mathrm{C}_{\text {вд }}$ \% від належного & 84,71 & 3,43 & 96,43 & 2,29 & $<0,01$ \\
\hline $\mathrm{PO}_{\text {вид, }}$ \% від належного & 67,38 & 2,31 & 71,75 & 3,67 & $<0,01$ \\
\hline дО, л & 0,29 & 0,04 & 0,31 & 1,04 & $>0,05$ \\
\hline ЧД, вд·хв ${ }^{-1}$ & 15,35 & 0,98 & 14,86 & 0,79 & $>0,05$ \\
\hline ХВЛ, л·Хв ${ }^{-1}$ & 4,52 & 0,69 & 4,79 & 0,79 & $>0,05$ \\
\hline $\mathrm{T}_{\text {вд }}, \mathrm{c}$ & 1,45 & 0,13 & 1,41 & 0,11 & $>0,05$ \\
\hline $\mathrm{T}_{\text {вид, }} \mathrm{c}$ & 2,48 & 0,24 & 2,60 & 0,24 & $>0,05$ \\
\hline ДО/Т & 0,20 & 0,03 & 0,22 & 0,03 & $>0,05$ \\
\hline $\mathrm{T}_{\text {вд }} /\left(\mathrm{T}_{\text {вд }}+\mathrm{T}_{\text {вид }}\right)$, ум.од. & 37,13 & 3,28 & 36,64 & 3,24 & $>0,05$ \\
\hline
\end{tabular}

Значення показника ЖЕЛ після проходження занятть зросло на $12,41 \%$ до 90,35 $\pm 1,67 \%$. Це вказує на ефективність аквааеробіки у дітей молодшого шкільного віку з хронічним бронхітом, наявність у цих дітей резервів функції зовнішнього дихання, котрі можуть бути активовані засобами фізичної реабілітації. Тож треба зазначити, що використання фізичних вправ у воді, та їх застосування призводить до збільшення показника ЖЕЛ у дітей.

Аналогічний аналіз був проведений і зі значеннями

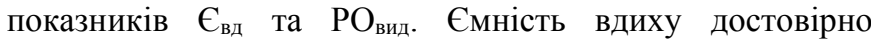
відрізнялася при порівнянні до та після проведення занять з аквааеробіки. Показник $\epsilon_{\text {вд }}$ зріс після проходження курсу

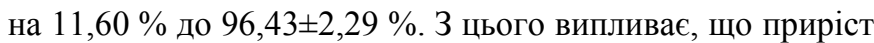
$\epsilon_{\text {вд }}$ був вищим після закінчення занятть, що у свою чергу свідчить про гарну оборотність зниження і про наявність суттєвих резервів.

Виявлена наступна динаміка показника $\mathrm{PO}_{\text {вид. До }}$

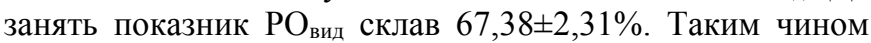
заняття з аквааеробіки позитивно вплинули на збільшення резервного об'єму видиху у дітей молодшого шкільного віку, хворих на рецидивуючий бронхіт.

Аналіз змін ДО та ЧД встановив, що дихальний об'єм не змінився порівняно з початковими значеннями у дітей ( $>0,05)$, а частота дихання достовірно зменшилася після занять $з$ аквааеробіки $(\mathrm{p}<0,01)$. 
Приведена динаміка дихального об'єму та частоти дихання вплинула на достовірні зміни хвилинної вентиляції легень у дітей молодшого шкільного віку $(\mathrm{p}<0,01)$. Відзначено статистичне зменшення ХВЛ у дітей після занять 3 аквааеробіки $35,72 \pm 0,85$ л·хв ${ }^{-1}$ до $4,59 \pm 0,70$ л $\mathrm{Xв}^{-1}$.

Показник $\mathrm{T}_{\text {вд }}$ достовірно не змінився, проте значення показника $\mathrm{T}_{\text {вид, }}$ зросли порівняно 3 початковими у дітей, хворих на хронічний бронхіт $(\mathrm{p}<0,01)$. Тривалість вдиху залишилася достовірно коротшою за тривалість фази видиху $(\mathrm{p}<0,001)$. Відношення тривалості вдиху до часу повного дихального циклу $\left(\mathrm{T}_{\text {вд }} /\left(\mathrm{T}_{\text {вд }}+\mathrm{T}_{\text {вид }}\right)\right)$ не відрізнялося у дітей після проходження занять 3 аквааеробіки, але було достовірно меншим порівняно зі значеннями на момент до проходження занять і склало у

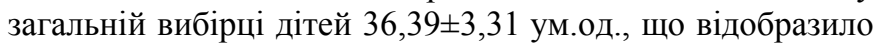
фізіологічність відношення тривалості фаз вдиху і видиху.

\section{Перспективи подальших досліджень}

Провести спірографічне дослідження для визначення ступеня вентиляційних порушень: проведення тесту форсованої життєвої ємності легень, що включав би дихальні маневри максимального форсованого видиху і вдиху.

\section{Висновки}

Отримані результати аналізу динаміки досліджуваних показників підтверджують, що у дітей 3 хронічним бронхітом в стадії ремісії, корті займалися аквааеробікою відбулись позитивні зміни основних об’ємних показників спірографії.

\section{Література}

1. Христова Т. С. Сучасні підходи до фізичної реабілітації дітей, які часто хворіють на гострі респіраторні захворювання / Т. С. Христова // Педагогіка, психологія та медико-біологічні проблеми фізичного виховання і спорту. - 2012. - № 5. - С. 119-123.

2. Антипкін Ю. Г. и др. Динаміка захворюваності та поширеності бронхолегеневої патології у дітей // Современная педиатрия. - 2016. - №. 2. - С. 73-77.

3. Состояние антиоксидантного статуса и некоторых звеньев иммунитета у детей с рецидивирующим бронхитом и бронхиальной астмой при применении полиоксидония / Ю. В. Шувалова, Н. Г. Герасимова, Т. Б. Ахвердиева и др. / Фундаментальные исследования. - 2014. - № 7-2. - С. 393-397.

4. Дудченко Л.Ш. Имунореабилитация детей, больных рецидивирующим бронхитом, на этапе санаторнокурортного лечения / Л.Ш. Дудченко, Н.Н. Каладзе // Вестник физиотерапии и курортологии. - 2004. - №1. - С. 6-12.

5. Ершова И.Б. Новые возможности профилактики и терапии респираторных заболеваний у детей / И.Б. Ершова, Т.Ф. Осипова, Л.М. Осычнюк // Укр. медичний альманах. - 2012. - №3. - С. 80-81.

6. Агзамова Ш. А. Характеристика нарушений вентиляции легких у детей с острыми и рецидивирующими бронхитами / Ш. А. Агзамова / Материалы Х Конгресса педиатров России «Актуальные проблемы педиатрии»: 6-9 февраля 2006 г., г. Москва. - С. 11-12.

7. Применение физических упражнений в воде на санаторном этапе реабилитации детей с бронхолегочной патологией / И. Е. Никитина, Е. И. Бычкова, А. Н. Шкребко, В. А. Маргазин / Материалы II Всероссийской научнопрактической конференции с международным участием «Лечебная физическая культура: достижения и перспективы развития» (27-28 мая 2013г.). - М.: ФГБОУ ВПО «РГУФКСМиТ», 2013. - 185-187.

\section{References}

1. Hristova TE. Modern approaches to physical rehabilitation of children who often suffer from acute respiratory diseases. Pedagogy, psychology and medic-biological problems of physical education and sports. 2012.; № 5: 119-123.

2. Antipkin YG, etc. The dynamics of the incidence and prevalence of bronchopulmonary pathology in children. Modern Pediatrics. 2016; № 2: 73-77.

3. Shuvalova YuV., Gerasimova NG, Akhverdieva TB, etc. The state of antioxidant status and some parts of immunity in children with recurrent bronchitis and bronchial asthma with the use of polyoxidonium. Fundamental research. 2014; № 7 (2): 393-397.

4. Dudchenko LSh. Immunorehabilitation of children with recurrent bronchitis at the stage of sanatorium treatment. Bulletin of Physiotherapy and Balneology. 2004; №1: 6-12.

5. Ershova IB. New opportunities for prevention and treatment of respiratory diseases in children. Ukr. medical almanac. 2012; №3: 80-81.

6. Agzamova ShA. Characteristics of lung ventilation disorders in children with acute and recurrent bronchitis. Proceedings of the X Congress of Pediatricians of Russia "Actual problems of pediatrics": February 6-9, 2006; Moscow: 11-12.

7. Nikitina IE, Bychkova EI, Shkrebko AN, Margazin VA. Application of physical exercises in water at the sanatorium stage of rehabilitation of children with bronchopulmonary pathology. Proceedings of the II All-Russian scientific-practical 
conference with international participation "Therapeutic physical culture: achievements and prospects for development" May 27-28, 2013; 185-187.

Дата надходження рукопису до редакції: 11.06 .2020 р.

\begin{abstract}
Мета: оцінити вплив аквааеробіки на функціональний стан системи дихання та толерантності до фізичних навантажень, у дітей молодшого шкільного віку, хворих на хронічний бронхіт в стадії ремісії.

Об'скт і методи. У ході аналізу історій хвороб нами були використані дані дітей (n = 109), що були скеровані та поступали на санаторно-курортне лікування до санаторію «Малятко» (м. Ужгород), з діагнозом «хронічний бронхіт».

Застосування спірографічного методу дослідження дозволило отримати дані про об'ємні показники, що відображають функціональні можливості системи дихання.

Результати. Спірографічне дослідження обмежувалося одним тестом для діагностики типу і ступеня вентиляційних порушень: проведенням тесту життєвої ємності легень (ЖСЛ). Дані, представлені в статті, відображають стан системи дихання дітей з ХБ до і після занять з аквааеробіки.

Достовірні відмінності між показниками до і після занять встановлені по ЖСЛ (p<0,01), Евд (p<0,01) і РОвид $(\mathrm{p}<0,01)$. Заняття 3 аквааеробіки позитивно вплинули на функцію зовнішнього дихання, що підтверджується достовірним збільшенням життєвої ємності легень, і відповідно ії складових, у всіх показниках (p<0,001).

Висновки. Отримані результати аналізу динаміки досліджуваних показників підтверджують, що у дітей 3 хронічним бронхітом в стадії ремісії, корті займалися аквааеробікою відбулися позитивні зміни основних об’ємних показників спірографії.
\end{abstract}

Ключові слова: дихальна система, хронічний бронхіт, діти молодшого шкільного віку.

Цель: оценить влияние аквааэробики на функциональное состояние системы дыхания и толерантности к физическим нагрузкам, у детей младшего школьного возраста, больных хроническим бронхитом в стадии ремиссии.

Объект и методы. В ходе анализа историй болезней нами были использованы данные детей $(\mathrm{n}=109)$, которые были направлены и поступали на санаторно-курортное лечение в санаторий «Малютка» (г. Ужгород), с диагнозом «хронический бронхит».

Применение спирографическое метода исследования позволило получить данные о объемные показатели, отражающие функциональные возможности системы дыхания.

Результаты. Спирографическое исследования ограничивалось одним тестом для диагностики типа и степени вентиляционных нарушений: проведением теста жизненной емкости легких (ЖЕЛ). Данные, представленные в статье, отражают состояние системы дыхания детей с ХБ до и после занятий по аквааэробике.

Достоверные различия между показателями до и после занятий установлены по ЖЕЛ (p<0,01), Евд (p<0,01) и РОвыд $(\mathrm{p}<0,01)$. Занятия по аквааэробике положительно повлияли на функцию внешнего дыхания, что подтверждается достоверным увеличением жизненной емкости легких, и соответственно ее составляющих, во всех показателях $(\mathrm{p}<0,001)$.

Выводы. Полученные результаты анализа динамики исследуемых показателей подтверждают, что у детей с хроническим бронхитом в стадии ремиссии, корте занимались аквааэробикой состоялись положительные изменения основных объемных показателей спирографии.

Ключевые слова: дыхательная система, хронический бронхит, дети младшего школьного возраста.

Aim of the study: to evaluate the effect of aqua aerobics on the functional state of the respiratory system and exercise tolerance, in young schoolchildren with chronic bronchitis in remission.

Object and methods. In the course of the analysis of medical histories we used data from children $(\mathrm{n}=109)$, who were sent and received for sanatorium-resort treatment to the sanatorium "Malatko" (Uzhhorod), diagnosed with "chronic bronchitis".

The use of a spirographic method of study allowed us to obtain data on volumetric indicators that reflect the functionality of the respiratory system.

Results. The spirographic study was limited to one test to diagnose the type and extent of ventilatory disorders: conducting a lung capacity test (VCL).

Data presented reflect the state of the respiratory system of children with HB before and after aqua aerobics classes. Significant differences between the indicators before and after the classes were established for VCL $(p<0.01)$, Eud ( $p<0.01)$ and ROV $(\mathrm{p}<0.01)$.

Aqua aerobics classes positively influenced the function of external respiration, which is confirmed by a significant increase in the vital capacity of the lungs, and accordingly its components, in all indicators.

The value of VCL after the session increased by $12.41 \%$ to $90.35 \pm 1.67 \%$. This indicates the effectiveness of aqua aerobics in young schoolchildren with chronic bronchitis, the presence in these children of reserves of the function of external respiration, which can be activated by means of physical rehabilitation. Therefore, it should be noted that the use of exercise in water, and their use leads to an increase in the rate of VLDL in children. 
A similar analysis was conducted with the values of Eud and ROvid indicators. The breath capacity was significantly different when compared to and after aqua aerobics classes. The EWD indicator increased after the course by $11.60 \%$ to $96.43 \pm 2.29 \%$. It follows that the increase in Eud was higher after graduation, which in turn indicates a good reversal of the decline and the presence of significant reserves.

The following dynamics of the ROI index were detected. Prior to the classes, the ROAD index was $67.38 \pm 2.31 \%$. In this way, aqua aerobics classes have had a positive effect on increasing the exhalation reserve in young schoolchildren with recurrent bronchitis.

Conclusions. The results of the analysis of the dynamics of the investigated parameters confirm that in children with chronic bronchitis in remission, the courts engaged in aqua aerobics, there were positive changes in the main volume indices of spirography.

Key words: respiratory system, chronic bronchitis, children of primary school age.

Конфлікт інтересів: відсутній.

Conflicts of interest: authors have no conflicts of interest to declare.

\section{Відомості про авторів}

Сабадош Мар'яна Володимирівна - к. н. 3 фіз. вих. і спорту, викладач кафедри фізичної реабілітації факультету здоров’я та фізичного виховання ДВНЗ «Ужгородський національний університет»; вул. Митна, 29, м. Ужгород, Закарпатська обл., 88000 , Україна.

sabadosh.marjana777@gmail.com.

Дуткевич-Іванська Юлія Василівна - старший викладач кафедри основ медицини факультету здоров'я та фізичного виховання ДВНЗ «Ужгородський національний університет»; вул. Митна, 29, м. Ужгород, Закарпатська обл., 88000, Україна.

yuliya101010@ukr.net.

Русин Людмила Петрівна - к.мед.н., доцент кафедри основ медицини факультету здоров'я та фізичного виховання ДВНЗ «Ужгородський національний університет»; вул. Митна, 29, м. Ужгород, Закарпатська обл., 88000, Україна. ljudarusyn@gmail.com. 